\section{Is the cytoplasm a site of nuclear DNA synthesis?}

OBSERVATIONS which do not harmonise with the original selfreplicative scheme of DNA synthesis have received little attention. In particular, interest in cytoplasmic DNA synthesis in eukaryotic cells has been limited to semiautonomous structures which contain DNA templates. But it was pointed out ${ }^{1}$ as early as 1958 that transfer of genetic information between DNA, RNA and protein often can proceed in either direction. It is possible that an initial step of DNA synthesis, corresponding for example to RNA-primed synthesis of Okazaki fragments $^{2,3}$, may generally occur out of cell nuclei and without direct participation of a DNA template. cytoplasmic fraction by nuclear DNA during the homogenate fractionation. I have therefore come to the conclusion that the cytoplasmic DNA synthesis may represent a prenuciear stage of the genome replication.

I thank E. Kraszewska for technical assistance. This work was supported by the Polish Academy of Sciences and, in part, by the US Department of Agriculture, Agricultural Research Service.

Polska Akademia Nauk,

J. Buchowicz

Instytut Biochemii i Biofizyki, 02-532 Warszawa, Poland

Received November 28, 1973; revised February 20, 1974.

${ }^{1}$ Chargaff, E., in The Origin of Life on the Earth (edit. by Oparin, A. I.), 297 (Pergamon Press, London, 1959).

Table 1 Incorporation of ${ }^{14} \mathrm{C}$-thymidine into nuclear, organellar and cytoplasmic DNA fractions of germinating wheat embryos

$\underset{\text { Germination }}{\text { time }}$

(h)

3

24
Nuclear

(d.p.m.)
$<10$
250
640
1,350
DNA amount and radioactivity (per 100 embryos) Organellar

$(\mu \mathrm{g})$
15
20
25
20

(d.p.m.)
$<10$
$<10$
40
150

$(\mu \mathrm{g})$
$<5$
$<5$
$<5$
$<5$

Cytoplasmic (d.p.m.) $<10$ 220 210 120

A sample of 350 wheat grains was surface sterilised with $2 \% \mathrm{NaClO}$ and left at $2 \% \mathrm{C}$ for $8 \mathrm{~h}$ with $10 \mathrm{ml}$ of ${ }^{14} \mathrm{C}$-thymidine solution(1.0 $\mu \mathrm{Ci}$ m1 ${ }^{-1}$, $\left.53 \mu \mathrm{C}-\mu \mathrm{mol}^{-1}\right)$. The prelabelled sample was washed with water and allowed to germinate at $22^{\circ} \mathrm{C}$ for the indicated time. Embryos were then separated and ground in a mortar with $10 \mathrm{ml}$ of ice-cold $0.25 \mathrm{M}$ sucrose containing $15 \mathrm{mM}$ potassium phosphate $(p \mathrm{H} 7.3)$ and $10 \mathrm{mM}$ $\mathrm{MgCl}_{2}$. The homogenate was filtered through a nylon tissue and fractionated by centrifugation. Nuclear $(1,000 \mathrm{~g}$ pellet $)$, organellar $(18,000 \mathrm{~g}$ pellet) and cytoplasmic $\left(18,000 \mathrm{~g}\right.$ supernatant) fractions were obtained and washed with $0.3 \mathrm{M} \mathrm{HClO}_{4}$ containing 1 mM thymidine. RNA was removed by an alkaline hydrolysis $\left(0.3 \mathrm{M} \mathrm{KOH}, 37^{\circ} \mathrm{C}, 15 \mathrm{~h}\right)$ and DNA fraction obtained as an acid hydrolysate $\left(0.5 \mathrm{M} \mathrm{HCl,} 100^{\circ} \mathrm{C}\right.$, $30 \mathrm{~min})$. The acid hydrolysate was applied to paper chromatography in a water-saturated butan-1-ol solvent system ${ }^{10}$. Adenine and guanine were eluted from the corresponding spots and determined spectrophotometrically to calculate the DNA content. The origin, containing a mixture of pyrimidine nucleotides resulting from the acid hydrolysis of DNA, was used for the measurement of radioactivity in a Packard liquid scintillation counter.

We tested for a prenuclear stage of DNA formation in germinating wheat embryo, in which biosynthetic events triggered after the breaking of dormancy are naturally synchronised ${ }^{4}$. It has been observed ${ }^{5}$ that incorporation of thymidine into DNA of germinating wheat seeds begins only after some preliminary activation of RNA synthesis is completed, implying an RNA-dependent DNA synthesis in this system. To check whether the cytoplasm may contribute to the early stage of DNA synthesis, wheat grains were prelabelled with ${ }^{14} \mathrm{C}$-thymidine and germinated for various periods. Total amounts and radioactivities of nuclear, organellar and cytoplasmic DNA of the embryo were then determined (Table 1).

I found that after $6 \mathrm{~h}$ germination radioactive DNA appeared in the nuclear and soluble cytoplasmic fractions (Table 1). Specific radioactivity of the cytoplasmic DNA was, however, at least 20 -fold higher than that of the nuclear DNA. As germination proceeded further the radioactivity of the cytoplasmic DNA decreased considerably and that of the nuclear DNA rose correspondingly. These observations are consistent with the hypothesis of a precursor-product relationship between the cytoplasmic and nuclear DNA. Rapid activation of cytoplasmic DNA synthesis in an early response to proliferative stimuli has been observed in other eukaryotic cells ${ }^{6-8}$. The experimental data do not exclude the possibility of an independent synthesis of the cytoplasmic and nuclear DNA. But the only explicable reason for the synthesis of deoxyribopolynucleotides in the supernatant fraction of the cytoplasm, which is virtually free of mature DNA molecules, is to supply them to the nucleus and other DNA-containing structures.

Another explanation is the transport of informational DNA from nucleus to cytoplasm, which has been reported for cultured animal cells. This explanation, however, can be hardly extended to the germinating wheat embryo, where radioactivity of the cytoplasmic DNA decreases after the nuclear DNA becomes highly radioactive. The same observation seems to exclude the possibility of a significant contamination of the
2 Okazaki, R., Okazaki, T., Sakebe, K., Sugimoto, K., Sugino, A., and Iwatsuki, N., Cold Spring Harbor Symp. quant. Biol., 33, $129(1968)$

${ }^{3}$ Okazaki, R., Sugino, A., Hirose, S., and Tamanoi, F., Ninth Int. Congress of Biochem., Stock holm, 126 (1973).

"Dobrzanska, M., Tomaszewski, M., Grzelczak, Z., Rejnan, E., and Buchowicz, J., Nature, 244, 507 (1973).

${ }^{5}$ Rejman, E., and Buchowicz, J., Phytochemistry, 10, 2951 (1971).

${ }^{6}$ Hanson, K. P., Ivanova, L. V., Nikitina, Z. S., Shutko, A. N., and Komar, V. E., Biokhimiya, 35, 635 (1970).

'Chang, L. M. S., and Bollum, F. J., J. biol. Chem., 247, 7958 (1972).

8 Chang, L. M. S., Brown, M. K., and Bollum, F. J., J, molec. Biol., 74, I (1973).

${ }^{9}$ Koch, J., and Pfeil, H. V., FEBS Lett., 24, 53 (1972).

10 Buchanan, J. G., Nature, 168, 1091 (1951).

\section{Effect of 5-bromodeoxyuridine on the size distribution of DNAs isolated from sea urchin embryos}

5-BROMODEOXYURIDINE (BUdR), an analogue of thymidine, has been shown to selectively inhibit cell differentiation in various cell types and development of embryos, without affecting cell maintenance capabilities'. Gontcharoff and Mazia ${ }^{2}$ demonstrated that exposure of newly fertilised sea urchin eggs or early cleavage stage embryos to BUdR resulted in embryos which did not gastrulate or produce echinochrome pigment. From this laboratory evidence has been reported" for a BUdR-induced modification of DNA replication in developing sea urchin embyros. Pulse-chase experiments in sea urchin gastrulae demonstrated that newly synthesised low molecular weight (8-15S) nuclear DNA labelled with "H-BUdR was not readily chased by unlabelled BUdR into higher molecular weight DNA. In contrast, 8-15S DNA labelled with " $\mathrm{H}$-thymidine was converted into higher molecular weight DNA during a relatively short chase period with unlabelled thymidire. This data suggested the incorporation of BUdR into newly synthesised low 